\title{
PENGARUH POLA ASUH ORANG TUA DAN TINGKAT EKONOMI KELUARGA TERHADAP HASIL BELAJAR PESERTA SISWA
}

\author{
Muh. Fais Fathoni ${ }^{1,}$ Dassucik $^{2} \&$ Ahmad Hafas Rasyidi ${ }^{3}$ \\ ${ }^{1}$ Mahasiswa Prodi Pendidikan Ekonomi STKIP PGRI Situbondo \\ ${ }^{2,3}$ Dosen Pendidikan Ekonomi STKIP PGRI Situbondo \\ Corresponding Email: asrorimuhammad670@gmail.com
}

\begin{abstract}
ABSTRAK
Tujuan penelitian ini suntuk mengetahui pengaruh pola asuh orang tua dan tingkat ekonomi keluarga terhadap hasil belajar siswa pada mata pelajaran IPS di MTs Fathus Salafi Mangaran semester genap tahun pelajaran 2020/2021. Teknik penentuan responden penelitian menggunakan proporsional random sampling. Dari hasil penelitian yang diperoleh dengan menggunakan rumus analisis variansi garis regresi menghasilkan Ry $(1,2)$ empiric sebesar 0,564 . Yang apabila dikonsultasikan dengan R-tabel dengan $\mathrm{N}$ sebanyak 100 responden dan taraf signifikansi 5\% diperoleh 0,195 perhitungan tersebut dimaksudkan untuk membuktikan hipotesa kerja mayor dengan menggukan uji signifikansi.

Dari hasil perhitungan analisis variansi garis regresi diperoleh $\mathrm{F}_{\text {reg }}$ sebesar 22,614 Dan apabila dikonsultasikan dengan $\mathrm{F}$ tabel untuk $\mathrm{db}=2 \mathrm{dan} \mathrm{db}=97$ dengan taraf signifikansi 5\% diperoleh 3,090. Dengan demikian dari hasil perhitungan tersebut menunjukkan Freg lebih besar dari F-tabel. Berdasarkan analisa data dimuka, maka hipotesa kerja mayor yang berbunyi "Ada pengaruh pola asuh orang tua dan tingkat ekonomi keluarga terhadap hasil belajar siswa pada mata pelajaran IPS di MTs Fathus Salafi Mangaran semester genap tahun pelajaran 2020/2021?" diterima.

Selanjutnya dalam efektifitas garis regresi dipreroleh sebesar $\mathbf{3 1 , 8 1 \%} \%$. Ini berarti sumbangan efektif dari keseluruhan prediktor hasil belajar siswa memberikan sumbangan sebesar 31,81\% dan variabel-variabel (faktor lain) yang tidak ikut di teliti sebesar $100 \%-\mathbf{3 1 , 8 1} \%=\mathbf{6 8 , 1 9} \%$ Sumbangan efektif $(\mathrm{SE})$ prediktor $\left(\mathrm{X}_{1}\right)$ pola asuh orang tua terhadap kriterium (Y) hasil belajar siswa 8,51\%, sumbangan efektif (SE) prediktor $\left(\mathrm{X}_{2}\right)$ tingkat ekonomi keluarga terhadap hasil belajar siswa $(\mathrm{Y})$ 38,27 $\%$, ini menunjukan bahwa tingkat ekonomi keluarga lebih berpengaruh terhadap hasil belajar siswa dibanding pola asuh orang tua.
\end{abstract}

Kata Kunci : Pola Asuh Orang tua, Hasil Belajar 


\section{PENDAHULUAN}

Pendidikan merupakan sarana yang sangat penting untuk menunjang kemajuan suatu bangsa dan meningkatkan sumber daya manusia yang berkualitas. Pendidikan berfungsi mewujudkan cita-cita suatu bangsa. Dalam arti luas pendidikan merupakan interaksi antara individu dengan lingkungan secara formal dan nonformal. Sedangkan dalam arti yang sempit, pendidikan merupakan interaksi dalam bentuk formal yang disebut proses belajar mengajar. Keberhasilan belajar seseorang bisa diukur dengan hasil belajarnya. Maka, hasil belajar siswa dapat diartikan sebagai kemampuan yang diperoleh anak setelah melalui kegiatan belajar. Ada banyak faktor yang mempengaruhi pencapaian hasil belajar, diantaranya yaitu pola asuh orang tua dan tingkat ekonomi keluarga.

Lingkungan keluarga sangat berpengaruh terhadap pendidikan, tingkah laku dan watak anak. Anak tumbuh dan berkembang dalam asuhan orang tua. Menurut Theo Riyanto (2012:89) pola asuh orang tua yang diberikan pada anak dalam bentuk perlakuan fisik maupun psikis yang tercermin dalam tutur kata, perilaku dan tindakan

yang diberikan. Melalui orang tua anak mendapatkan pendidikan untuk pertama kalinya. Sehingga pendidikan dari orang tua menjadi dasar pembentukan pribadi dan perkembangan anak.

Orang tua berhak memilih pola asuh yang diterapkan dalam kehidupan keluarga, tetapi apabila pola asuh yang diterapkan keliru maka perilaku anak juga tidak akan baik. Menurut M. Enock Markum pada penelitian Sugiharto (2012 : 312) orang tua harus bersikap demokratis, memberikan kebebasan pada anak untuk memilih apa yang disukainya, menyediakan diri untuk menjelaskan apa yang dilihat anak, serta berusaha mendengarkan apa yang ditanyakan anak. Pola asuh yang diterapkan oleh orang tua akan mempengaruhi tingkah laku anak yang akan berpengaruh pula terhadap hasil belajar di sekolah.

\section{KAJIAN PUSTAKA}

Pola asuh orang tua merupakan interaksi antara anak dan orang tua selama mengadakan kegiatan pengasuhan. Pengasuhan ini berarti orang tua menddidik, membimbing, dan mendisiplinkan, serta melindungi anak untuk mencapai 
kedewasaan sesuai dengan norma-norma yang ada dalam masyarakat. Menurut setiawan (dalam Hurlock, 2010) orang tua harus dapat memberikan pola asuh yang tepat sesuai dengan perkembangan anaknya, agar anak dapat menerina pola asuh yang diberikan kepadanya dengan baik sehingga dapat memotivasi belajarnya. Pola asuh orang tua adalah sikap orang tua dalam membimbing anaknya.

Pola asuh pada dasarnya diciptakan oleh adanya interaksi antara orang tua dan anak dalam hubungan sehari-hari yang berevolusi sepanjang waktu, sehingga orang tua akan menghasilkan anak anak sealiran, karena orang tua tidak hanya mengajarkan dengan kata-kata tetapi juga dengan contoh-contoh. Orang tua yang satu dengan orang tua yang lain memberikan pola asuh yang berbeda dalam membimbing dan mendidik anak-anaknya. Salah satu yang mempengaruhi hasil belajar adalah pola asuh orang tua terhadap anak. Pola asuh yang diterima seorang anak bersifat subjektif sehingga hasil belajarnya tergantung bagaimana anak menerima pola asuh yang diberikan orang tuanya. Dengan pola asuh yang diberikan orang tua akan membuat anak termotivasi dalam belajar.

Selain dipengaruhi oleh pola asuh orang tua, tingkat ekonomi keluarga juga berpengaruh terhadap hasil belajar siswa. Keluarga bertanggung jawab menyediakan dana untuk kebutuhan pendidikan anak. Dengan ekonomi keluarga yang baik, anak lebih berkesempatan mendapatkan fasilitas belajar yang baik pula. Sebalikya dengan ekonomi yang kurang, anak juga kurang mendapatkan fasilitas belajar yang baik pula. Orang tua mengharapkan nasib anaknya lebih baik dari mereka, maka dari itu orang tua berupaya memenuhi kebutuhan anaknya menurut kemampuan ekononomi mereka masing-masing (Indrawati 2011:1).

Slameto (2013: 54-72) menggolongkan fakto-faktor yang mempengaruhi belajar menjadi dua golongan, yaitu faktor internal dan eksternal, salah satu dari faktor eksternal adalah faktor keluarga. Siswa yang belajar akan menerima pengaruh dari keluarga salah satunya yaitu cara orang tua mendidik. Pola asuh orang tua mendidik anaknya besar pengaruhnya terhadap belajar anak. 
Hasil belajar siswa di MTs Fatus Salafi Mangaran ternyata masih rendah, informasi tersebut diperoleh dari hasil wawancara salah satu guru di sekolah tersebut pada bulan Februari.

Oleh karena itu penulis ingin melakukan penelitian dengan judul "Pengaruh Pola Asuh Orang Tua dan Tingkat Ekonomi Keluarga Terhadap Hasil Belajar Peserta Siswa Pada Mata Pelajaran IPS di MTs Fathus Salafi Mangaran Semester Genap Tahun Pelajaran 2020/2021.

\section{METODE PENELITIAN}

Penelitian ini merupakan penelitian jenis penelitian kuantitatif. Dalam penelitian kuantitatif, masalah yang dibawa oleh peneliti sudah jelas (Sugiyono, 2016:30). Dalam Penelitian ini peneliti menggunakan rancangan penelitian ex post facto. Penelitian disebut ex post facto karena para peneliti berhubungan dengan variabel yang telah terjadi dan mereka tidak perlu memberikan perlakuan terhadap variabel yang diteliti. Teknik penentuan lokasi yang digunakan oleh peneliti adalah purposive sampling area. Sedang yang menjadi objek penelitian siswa kelas VII, VIII dan IX yang berjumlah 112 peserta didik dan peneliti mengambil sampel sebanyak 100 siswa.. Sedangkan analisis data dalam penelitian ini dilakukan dengan uji regresi berganda.

\section{HASIL DAN PEMBAHASAN}

\section{ANALISIS DATA}

\section{Persamaan Garis Regresi}

$$
\begin{aligned}
\mathrm{Y} & =\mathrm{a}_{1}\left(x_{1}-\overline{x_{1}}\right)+\left(\overline{x_{2}}-\overline{x_{2}}\right)+\bar{Y} \\
\mathrm{Y} & =0,877\left(\mathrm{x}_{1}-23,53\right)+1,608\left(\mathrm{x}_{2}-17,84\right)+77,66 \\
& =0,877 \mathrm{x}_{1}-20,64+1,608 \mathrm{x}_{2}-28,69+77,66 \\
\mathbf{Y} & =\mathbf{0 , 8 7 7} \mathrm{x}_{1}+\mathbf{0 , 6 0 8} \mathbf{x}_{\mathbf{2}}+\mathbf{2 8 , 3 3}
\end{aligned}
$$

Dari perhitungan di atas dapat dituliskan persamaan garis regresinya untuk variabel bebas terhadap variabel terikatnya adalah:

\section{a. Konstanta}

Konstanta sebesar 28,33 mempunyai arti adanya pengaruh yang positif terhadap hasil belajar siswa yaitu pola asuh orang tua dan tingkat ekonomi keluarga 
tetap atau konstan, akan mempengaruhi hasil belajar siswa sebesar 28,33 dengan variabel pengganggu yang tidak tidak diteliti.

\section{b. Koefisien Regresi Pola Asuh Orang Tua $\left(\mathbf{X}_{1}\right)$}

Koefisien regresi pola asuh orang tua $\left(\mathrm{X}_{1}\right)$ menunjukkan besarnya perubahan variabel hasil belajar siswa (Y) sehubungan dengan perubahan variabel pola asuh orang tua dengan asumsi variabel tingkat ekonomi keluarga tetap (X2) atau konstan. Perubahan yang terjadi bersifat positif atau searah, artinya apabila salah satu variabel mengalami kenaikan, akan mengakibatkan kenaikan variabel lainnya. Apabila terjadi perubahan variabel pola asuh orang tua $\left(\mathrm{X}_{1}\right)$ sebesar $1 \%$ dengan anggapan variabel tingkat ekonomi keluarga $\left(\mathrm{X}_{2}\right)$ sama dengan nol menyebabkan perubahan variabel hasil belajar siswa (Y) sebesar $\mathbf{0 , 8 7 7 .}$

\section{c. Koefisien Regresi Tingkat Ekonomi Keluarga $\left(\mathrm{X}_{2}\right)$}

Koefisien regresi tingkat ekonomi keluarga $\left(\mathrm{X}_{2}\right)$ menunjukkan besarnya perubahan variabel hasil belajar siswa (Y) sehubungan dengan perubahan variabel tingkat ekonomi keluarga $\left(\mathrm{X}_{2}\right)$ dengan asumsi variabel pola asuh orang tua $\left(\mathrm{X}_{1}\right)$ konstan. Perubahan yang terjadi bersifat positif atau searah, artinya apabila salah satu variabel mengalami kenaikan, akan menyebabkan kenaikan variabel lainnya. Apabila terjadi perubahan tingkat ekonomi keluarga $\left(\mathrm{X}_{2}\right)$ sebesar $1 \%$ dengan anggapan variabel pola asuh orang tua $\left(\mathrm{X}_{1}\right)$ sama dengan nol menyebabkan perubahan variabel hasil belajar siswa sebesar $\mathbf{0 , 6 0 8}$.

\section{Koefisien Korelasi}

Menghitung koefisien korelasi berganda atau tingkat hubungan antara kriteria atau variabel terikat (Y) dengan prediktor/variabel bebas (X) dengan menggunakan rumus:

$$
\begin{aligned}
& \operatorname{Ry}_{(1,2)}=\sqrt{\frac{a_{1} \sum x_{1} y+a_{2} \sum x_{2} y}{\sum y^{2}}} \\
& =\sqrt{\frac{(0,877)(399,02)+(1,608)(595,56)}{4110,44}} \\
& =\sqrt{0,318} \\
& \operatorname{Ry}_{(1,2)}=0,564
\end{aligned}
$$




$$
\operatorname{Ry}^{2}(1,2)=0,318
$$

\section{Menghitung Analisis Varian Garis Regresi}

Setelah diketahui koefisien korelasinya kemudian dicari nilai Freg untuk mengetahui signifikan atau tidaknya nilai yang diperoleh antara dua variabel bebas secara serentak dengan variabel terikatnya, yaitu dengan rumus:

$$
\begin{aligned}
\mathrm{F}_{\text {reg }} & =\frac{R^{2}(N-m-1)}{m\left(1-R^{2}\right)} \\
& =\frac{0,318(100-2-1)}{2(1-0,318)}
\end{aligned}
$$

Freg $=22,614$

Dengan menggunakan rumus diatas dan memasukkan data-data yang ada, maka diperoleh nilai Freg $=22,614$. untuk mengetahui signifikansi atau tidaknya nilai Freg ini dikonsultasikan dengan F-tabel dengan derajat kebebasan untuk menguji tingkat signifikan harga Freg adalah $\mathrm{m}$ lawan $(\mathrm{N}-\mathrm{m}-1)$. Dalam kasus diatas $\mathrm{db}=2 / 97$. Untuk db = 2 lawan 97 yaitu harga F-tabel dengan taraf signifikan 5\% = 3,0902. Jadi Freg $=22,614$ itu signifikan, berarti hipotesa nihil (Ho) ditolak dan hipotesa kerja (Ha) diterima.

\section{Menghitung Efektifitas Garis Regresi (EGR)}

Untuk mengetahui besarnya pengaruh masing-masing prediktor terhadap besar kreterium dengan menggunakan analisis Sumbangan Efektif (SE) tiap-tiap prediktor $\mathrm{X}_{1}$ dan $\mathrm{X}_{2}$ terhadap kriterium $\mathrm{Y}$ dengan cara:

$$
\begin{aligned}
\mathrm{SE} \% \mathrm{X}_{1} & =\frac{a_{1} \sum x_{1} y}{J K_{\operatorname{Re} g}} x E G R \\
& =\frac{349,94054}{1.307,60102} \times 31,81 \% \\
& =8,51 \% \\
\mathrm{SE} \% \mathrm{X}_{2} & =\frac{a_{2} \sum x_{2} y}{J K_{\operatorname{Re} g}} x E G R \\
& =\frac{957,66048}{1.307,60102} \times 31,81 \% \\
& =23,30 \%
\end{aligned}
$$


Dari hasil perhitungan di atas dapat disimpulkan bahwa sumbangan efektif prediktor $\mathrm{X}_{1}$ terhadap kreterium $\mathrm{Y}$ sebesar 8,51 \%, sumbangan efektif prediktor $\mathrm{X}_{2}$ terhadap kreterium Y sebesar $\mathbf{2 3 ,} 30$ \%.

Pernyataan diatas menunjukkan bahwa variabel tingkat ekonomi keluarga yang paling dominan terhadap hasil belajar siswa. Hal ini terbukti dari proporsi sumbangan pola asuh orang tua dan tingkat ekonomi keluarga yang paling besar 23,30 \% bila dibandingkan variabel pola asuh orang tua sebesar 8,51 \%. Hasil rekapitulasi data hasil analisa data tertera dalam tabel dibawah ini:

Tabel 1 Hasil analisa data

\begin{tabular}{|c|l|r|r|r|}
\hline No. & \multicolumn{1}{|c|}{ Variabel Bebas } & EGR (\%) & SR (\%) & \multicolumn{1}{c|}{ SE } \\
\hline $\begin{array}{c}\text { 1. } \\
2 .\end{array}$ & $\begin{array}{l}\text { Pola asuh orang tua } \\
\text { Tingkat ekonomi keluarga }\end{array}$ & & 26.76 & $\mathbf{8 , 5 1}$ \\
\hline & \multicolumn{1}{|c|}{ Jumlah } & 31,81 & 100 & 31,81 \\
\hline 4. & $\begin{array}{l}\text { Variabel bebas lain yang } \\
\text { tidak diteliti }\end{array}$ & $\mathbf{6 8 , 1 9}$ & & $\mathbf{6 8 , 1 9}$ \\
\hline & Jumlah & $100 \%$ & $100 \%$ & $100 \%$ \\
\hline
\end{tabular}

Dari tabel diatas menunjukkan bahwa variabel tingkat ekonomi keluarga merupakan variabel yang paling dominan terhadap hasil belajar siswa. Hal ini terbukti dari proporsi sumbangan variabel yang paling besar yaitu sebesar 23,30 \% .

\section{PENGUJIAN HIPOTESIS}

\section{Pengujian Hipotesis Mayor}

Untuk mengetahui sejauh mana pengaruh antara pola asuh orang tua dan tingkat ekonomi keluarga dengan hasil belajar (hipotesa mayor) maka dapat dihitung dengan menghitung korelasi antara variabel $\mathrm{X}$ dan $\mathrm{Y}$ dengan rumus:

$$
\begin{aligned}
\operatorname{Ry}_{(1,2)} & =\sqrt{\frac{a_{1} \sum x_{1} y+a_{2} \sum x_{2} y}{\sum y^{2}}} \\
& =\sqrt{\frac{(0,877)(399,02)+(1,608)(595,56)}{4110,44}} \\
\operatorname{Ry}_{(1,2)} & =0,564
\end{aligned}
$$


Untuk mengetahui apakah hipotesa mayor yang diajukan diterima/ditolak maka harga R-hitung dibandingkan dengan R-tabel, dan hasil perbandingan R-tabel dengan taraf signifikansi 5\% dengan sampel 100 orang diperoleh $\mathrm{R}$-tabel $=0,195$ sedangkan hipotesa mayor $\mathrm{Ry}_{(1,2)}=0,564$.

Dari hasil perbandingan ternyata R-hitung lebih besar dari R-tabel artinya hipotesa kerja (Ha) diterima dan hipotesa nihil (Ho) ditolak, hipotesa kerja yang diterima adalah: "Ada pengaruh pola asuh orang tua dan tingkat ekonomi keluarga terhadap hasil belajar siswa" Nilai tersebut dikorelasikan dengan tabel interprestasi koefisien korelasi tabel interpretasi koefisien korelasi.

Tabel 2. Interpretasi koefisien korelasi

\begin{tabular}{|c|l|}
\hline \multicolumn{1}{|c|}{ Besar Nilai } & \multicolumn{1}{|c|}{ Interprestasi } \\
\hline Antara $\pm 0,00 \mathrm{~s} / \mathrm{d} \pm 0,20$ & Tidak ada / tidak ada pengaruh \\
Antara $\pm 0,21 \mathrm{~s} / \mathrm{d} \pm 0,40$ & Pengaruh rendah \\
Antara $\pm 0,41 \mathrm{~s} / \mathrm{d} \pm 0,60$ & Pengaruh sedang \\
Antara $\pm 0,61 \mathrm{~s} / \mathrm{d} \pm 0,80$ & Pengaruh tinggi \\
Antara $\pm 0,81 \mathrm{~s} / \mathrm{d} \pm 1,00$ & Pengaruh sempurna \\
\hline
\end{tabular}

Setelah dikonsultasikan dengan tabel interprestasi diatas, maka nilai 0,564 terletak antara $\pm 0,41 \mathrm{~s} / \mathrm{d} \pm 0,60$ berarti pengaruh pola asuh orang tua dan tingkat ekonomi keluarga terhadap hasil belajar adalah pengaruh sedang.

\section{Pengujian Hipotesis Minor I}

Untuk mengetahui sejauh mana pengaruh antara pengaruh pola asuh orang tua dengan hasil belajar (hipotesa minor pertama) maka dapat dihitung dengan menghitung korelasi antara variabel $\mathrm{X}_{1}$ dan $\mathrm{Y}$ dengan rumus:

$$
\begin{aligned}
\operatorname{Ry}_{1(2)} & =\frac{R y_{1}-R y_{2} R_{12}}{\sqrt{\left(1-\left(R y_{2}\right)^{2}\right)\left(1-\left(R_{12}\right)^{2}\right)}} \\
& =\frac{0,365-(0,518)(0,293)}{\sqrt{\left(1-0,518^{2}\right)\left(1-0,293^{2}\right)}} \\
\operatorname{Ry}_{1(2)} & =0,260
\end{aligned}
$$


Untuk mengetahui apakah hipotesis minor pertama yang diajukan diterima atau ditolak maka harga R-hitung dibandingkan dengan R-tabel. Hasil pengujian hipotesis selengkapnya adalah sebagai berikut: pada taraf signifikansi 5\% dengan jumlah responden 100 orang diperoleh R-tabel sebesar 0,195 bila dibandingkan pada perhitungan Ry2 sebesar 0,260 dengan R-tabel 0,195 maka nilai R-hitung > R-tabel, artinya hipotesa nihil (Ho) ditolak dan hipotesa kerja (Ha) diterima. Hipotesa kerja (Ha) yang diterima adalah: "Ada pengaruh pola asuh orang tua terhadap hasil belajar siswa" Setelah dikonsultasikan dengan tabel interpretasi diatas, maka nilai 0,365 terletak antara $\pm 0,21 \mathrm{~s} / \mathrm{d} \pm 0,40$ berarti pengaruh pola asuh orang tua $\left(\mathrm{X}_{1}\right)$ dengan hasil belajar siswa adalah pengaruh rendah.

\section{Pengujian Hipotesis Minor II}

Untuk mengetahui sejauh mana pengaruh antara tingkat ekonomi keluarga dengan hasil belajar (hipotesa minor kedua) maka dapat dihitung dengan menghitung korelasi antara variabel $\mathrm{X}_{2}$ dan $\mathrm{Y}$ dengan rumus:

$$
\begin{aligned}
\operatorname{Ry}_{2(1)} & =\frac{R y_{2}-R y_{1} R_{12}}{\sqrt{\left(1-\left(R y_{1}\right)^{2}\right)\left(1-\left(R_{12}\right)^{2}\right)}} \\
& =\frac{0,518-(0,365)(0,293)}{\sqrt{\left(1-0,365^{2}\right)\left(1-0,293^{2}\right)}} \\
\operatorname{Ry}_{2(1)} & =0,462
\end{aligned}
$$

Untuk mengetahui apakah hipotesis minor kedua yang diajukan diterima atau ditolak maka harga R-hitung dibandingkan dengan R-tabel. Hasil pengujian hipotesis selengkapnya adalah sebagai berikut: pada taraf signifikansi 5\% dengan jumlah responden 100 orang diperoleh $\mathrm{R}$-tabel sebesar 0,195 pada perhitungan $\mathrm{Ry}_{2}$ sebesar 0,462. Bila dibandingkan dengan R-tabel maka nilai R-hitung > R-tabel, artinya hipotesa nihil (Ho) ditolak dan hipotesa kerja (Ha) diterima. Hipotesa kerja (Ha) yang diterima adalah: "Ada pengaruh tingkat ekonomi keluarga terhadap hasil belajar" Setelah dikonsultasikan dengan tabel interprestasi diatas, maka nilai 0,462 terletak antara $\pm 0,41 \mathrm{~s} / \mathrm{d} \pm 0,60$ berarti pengaruh tingkat ekonomi keluarga terhadap hasil belajar siswa adalah pengaruh sedang. Untuk lebih jelasnya dari hasil seluruh perhitungan mencari besar pengaruh dapat dilihat pada tabel berikut: 
Tabel 3. Pengujian Hipotesa Mayor dan Minor

\begin{tabular}{|l|c|c|l|l|}
\hline \multicolumn{1}{|c|}{ Hipotesis } & R.Empirik & R.Tabel & \multicolumn{1}{|c|}{ Keputusan } & Sumbangan \\
\hline Ha Mayor & 0,564 & 0,195 & Signifikan & $31,81 \%$ \\
Ha Minor 1 & 0,260 & 0,195 & Signifikan & $8,51 \%$ \\
Ha Minor 2 & 0,462 & 0,195 & Signifikan & $23,30 \%$ \\
\hline
\end{tabular}

\section{PEMBAHASAN}

Dari hasil penelitian yang diperoleh dengan menggunakan rumus analisis variansi garis regresi menghasilkan Ry $(1,2)$ empiric sebesar 0,564. Yang apabila dikonsultasikan dengan R-tabel dengan $\mathrm{N}$ sebanyak 100 responden dan taraf signifikansi $5 \%$ diperoleh 0,195 perhitungan tersebut dimaksudkan untuk membuktikan hipotesa kerja mayor dengan menggukan uji signifikansi.

Dari hasil perhitungan analisis variansi garis regresi diperoleh $F_{\text {reg }}$ sebesar 22,614 Dan apabila dikonsultasikan dengan F tabel untuk $\mathrm{db}=2$ dan $\mathrm{db}=97$ dengan taraf signifikansi 5\% diperoleh 3,090. Dengan demikian dari hasil perhitungan tersebut menunjukkan Freg lebih besar dari F-tabel.

Berdasarkan analisa data dimuka, maka hipotesa kerja mayor yang berbunyi "Ada pengaruh pola asuh orang tua dan tingkat ekonomi keluarga terhadap hasil belajar siswa pada mata pelajaran IPS di MTs Fathus Salafi Mangaran semester genap tahun pelajaran 2020/2021?" diterima.

Selanjutnya dalam efektifitas garis regresi dipreroleh sebesar $\mathbf{3 1 , 8 1 \%} \%$. Ini berarti sumbangan efektif dari keseluruhan prediktor hasil belajar siswa memberikan sumbangan sebesar 31,81\% dan variabel-variabel (faktor lain) yang tidak ikut di teliti sebesar $100 \%-\mathbf{3 1 , 8 1} \%=\mathbf{6 8 , 1 9} \%$

Sumbangan efektif $(\mathrm{SE})$ prediktor $\left(\mathrm{X}_{1}\right)$ pola asuh orang tua terhadap kriterium (Y) hasil belajar siswa 8,51\%, sumbangan efektif $(\mathrm{SE})$ prediktor $\left(\mathrm{X}_{2}\right)$ tingkat ekonomi keluarga terhadap hasil belajar siswa (Y) 38,27 \%, ini menunjukan bahwa tingkat ekonomi keluarga lebih berpengaruh terhadap hasil belajar siswa dibanding pola asuh orang tua. 
Pola asuh merupakan cara orang tua mendidik, bertindak, berinteraksi dan membimbing anak sebagai suatu aktivitas yang melibatkan banyak perilaku secara individual maupun bersama-sama sebagai serangkaian usaha aktif untuk mengarahkan anak dalam belajar. Orang tua dengan perilaku ini bersikap rasional, selalu mendasari tindakannya pada rasio atau pemikiran-pemikiran. Orang tua tipe ini juga memberikan kebebasan kepada anak untuk memilih dan melakukan suatu tindakan dengan cara pendekatan yang bersifat hangat (Ira Petranto, 2015:43).

Otoriter adalah pola asuh yang cenderung menetapkan standar yang mutlak harus dituruti, biasanya disertai ancaman-ancaman. Pola asuh ini ditandai dengan adanya aturan-aturan yang kaku dari orang tua. Kebebasan anak sangat dibatasi, orang tua memaksa anak untuk berperilaku seperti yang diinginkannya.

Permisif adalah pola asuh yang memberikan kesempatan pada anak untuk melakukan sesuatu tanpa pengawasan yang cukup dari orang tua. Anak dipandang sebagai makhluk hidup yang berpribadi bebas. Mereka cenderung tidak menegur atau memperingatkan anak apabila anak sedang dalam bahaya dan sangat sedikit bimbingan yang diberikan oleh orang tua (Ira Petranto, 2010:21). Seorang anak yang belum pernah diajari untuk mentoleransi frustasi, karena ia diperlakukan terlalu baik oleh orang tuanya, akan menemukan banyak masalah ketika dewasa

Keluarga merupakan lembaga sosial pertama yang memberikan pengaruh bagi perkembangan anak misalnya anak yang berasal dari keluarga yang tingkat sosial ekonomi tinggi secara otomatis tidak mengalami hambatan dan kesulitan dalam memenuhi kebutuhannya, baik kebutuhan jasmani maupun rohani. Keluarga dengan ekonomi cukup atau tinggi pada umumnya akan lebih mudah memenuhi segala kebutuhan sekolah dan keperluan lain. Berbeda dengan keluarga yang ekonominya rendah, pada umumnya mengalami kesulitan dalam pembiayaan sekolah, begitu juga dengan keperluan lain. Slameto (2013:65) menjelaskan bahwa keadaan ekonomi keluarga erat hubungannya dengan hasil belajar anak. Dengan terpenuhinya kebutuhan seseorang dapat bertambah semangat dan bergairah untuk hidup dalam usahanya. 
Keluarga merupakan lembaga sosial pertama yang dikenal oleh anak dan dalam keluarga ini dapat ditanamkan sikap-sikap yang dapat mempengaruhi perkembangan anak selanjutnya. Keluarga bertanggung jawab menyediakan dana untuk kebutuhan pendidikan anak. Keluarga (orang tua) yang tingkat ekonomi tinggi tidak akan banyak mengalami kesulitan dalam memenuhi kebutuhan sekolah anak, berbeda dengan orang tua yang tingkat ekonominya rendah.

\section{KESIMPULAN}

Berdasarkan hasil penelitian, analisa data dan pengujian hipotesa penulis, maka dapat diambil kesimpulan sebagai berikut:

1. Ada pengaruh pola asuh orang tua dan tingkat ekonomi keluarga terhadap hasil belajar siswa pada mata pelajaran IPS di MTs Fathus Salafi Mangaran semester genap tahun pelajaran 2020/2021.

2. Ada pengaruh pola asuh orang tua terhadap hasil belajar siswa pada mata pelajaran IPS di MTs Fathus Salafi Mangaran semester genap tahun pelajaran 2020/2021.

3. Ada pengaruh tingkat ekonomi keluarga terhadap hasil belajar siswa pada mata pelajaran IPS di MTs Fathus Salafi Mangaran semester genap tahun pelajaran 2020/2021.

\section{DAFTAR PUSTAKA}

Abdurrahman, M. 2010. Pendidikan Bagi Anak Kesulitan Belajar. Jakarta; PT. Rineka Cipta.

Ahmadi, Abu., dkk. 2011. Ilmu Pendidikan (Cetakan ke II). Jakarta; PT. Rineka Cipta.

Arifin, Z. 2009. Evaluasi Pembelajaran. Bandung; PT. Remaja Rosdakarya.

Arikunto, 2012. Prosedur Penelitian Suatu Pendekatan Praktik. Jakarta; Rineka.

Arikunto, Suharsimi. 2007. Manajemen Penelitian, Jakarta; PT. Rineka Cipta.

Budiningsih, Asri. 2010. Belajar dan Pembelajaran. Jakarta; PT Rineka Cipta.

Cholid Narbuko, 2009. Metode penelitian pendidikan. Bandung; Alfabeta

Darmadi, Hamid. 2011. Metode penelitian pendidikan. Bandung; Alfabeta.

Dimyati danMudjiono, 2012 Belajar dan Pembelajaran. Jakarta; PT Rineka Cipta. 
Hamalik, Oemar. 2013. Proses Belajar Mengajar. Jakarta; Bumi Aksara.

Hakim, T. 2011. Belajar Secara Efektif. Jakarta; Puspa Swara.

Ishaq. 2011. Menyusun Rencana Penelitian. Jakarta; Rineka Cipta.

Idris, 2012. Administrasi Pendidikan. Jakarta : Bumi Aksara

Irwanto, 2011. Pendidikan Keluarga Narkotika, Jakarta : Acuan

Muhammad, Masrob, 2015. Administrasi Pendidikan. Jakarta. Rineka Cipta.

Nasution. 2008. Berbagai Pendekatan Suatu Proses Belajar Mengajar. Jakarta; Bumi aksara.

Purwanto, Ngalim. 2013. Evaluasi Hasil Belajar. Surakarta; Pustaka Pelajar.

Riduwan. 2012. Belajar Mudah Penelitian. Bandung; Alfabeta.

Slameto, 2013. Belajar dan Faktor-Faktor Yang Mempengaruhina. Jakarta; Rineka Cipta

Sudjana, Nana. 2011. Metode Statistika. Bandung; Tarsito.

Sugiyono. 2014. Statistika untuk Penelitian. Bandung; Balai Pustaka.

Sukardi, 2011. Metode Penelitian Kuantitatif, kualitatif dan $R$ \& D. Bandung; Alfabeta.

Sutrisno Hadi, 2011. Statistika untuk Penelitian. Bandung; Balai Pustaka

Tanjung, 2011. Perubahan Sosial dan Pendidikan: Pengantar Pedagogik Transformatif untuk Indonesia. Jakarta: Grasindo

Usman, 2012 Paradigma Baru Manajemen Sumber Daya Manusia. Yogyakarta: Amara Books

Undang-Undang Republik Indonesia Nomor 14 Tahun 2005 tentang Guru dan Dosen serta Undang-Undang Republik Indonesia Nomor 20 tahun 2003 tentang Sistem Pendidikan Nasional. 2006. Bandung Citra Umbara.

Yatim Riyanto, 2011. Metode Penelitian Kuantitatif, kualitatif. Bandung; Alfabeta. 